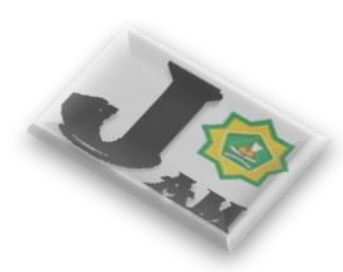

Al-Muqayyad

ISSN (print): 2715-3177 | ISSN (online): 2614-8102

Program Studi Ekonomi Syariah, STAI Auliaurrasyidin Tembilahan

Journal Homepage: https://ejournal.stai-tbh.ac.id/index.php/al-muqayyad

\title{
Pengaruh Musaqah terhadap tingkat Kesejahteraan Petani Kelapa
}

* Nursupiana Rastini ${ }^{1, a}$, Hendro Lisa ${ }^{2, b}$ Selviani ${ }^{3, c}$

1,2,3) STAI Auliaurrasyidin Tembilahan, Indragiri Hilir, Riau, Indonesia.

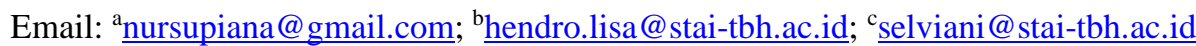

DOI: $\quad$ Cara Mensitasi Artikel ini:

https://doi.org/10.469 Rastini, N., Lisa, H., Selviani, S. (2021). Pengaruh musaqah terhadap tingkat

63/jam.v4i2.478 kesejahteraan petani kelapa. AL-Muqayyad, 4(2), 144-152.

https://doi.org/10.46963/jam.v4i2.478

\section{Keywords: \\ Musaqah, Welfare \\ Level and Coconut \\ Farmers}

\section{Kata Kunci:}

Musaqah, Tingkat

Kesejahteraan dan

Petani Kelapa

\section{Informasi Artikel:}

Diterima:

02/12/2021

Direvisi:

Diterbitkan

$30 / 12 / 2021$

*Corresponding

Author

nursupiana@gmail.co

$\mathrm{m}$

\section{ABSTRACT}

The purpose of this study was to determine the effect, significance value and percentage of musaqah on the welfare level of coconut farmers, especially coconut farmers.This type of research is quantitative research, namely analyzing in the form of data in the form of numbers. Sampling with random sampling technique.The results of this study indicate that the t-count value is 4.229 so that the t-table is $1.972<t$-count is 4.229 with a significance of $0.000<0.005$. Thus, it can be concluded that musaqah influences the level of welfare of coconut farmers and has a significant effect. The percentage of musaqah influence on the welfare level of coconut farmers is $25.3 \%$, while the remaining $74.7 \%$ is influenced by other variables not included in this study.

\section{ABSTRAK}

Tujuan penelitian ini untuk mengetahui pengaruh, nilai signifikansi dan besar persentase musaqah pada tingkat kesejahteraan petani kelapa khususnya petani kelapa penggarap. Jenis penelitian ini adalah penelitian kuantitatif, yaitu menganalisis dalam bentuk data-data yang berupa angka. Pengambilan sampel dengan teknik random sampling. Hasil penelitian ini menunjukkan nilai $t$ hitung sebesar 4,229 sehingga t tabel 1,972 < t hitung 4,229 dengan signifikansi 0,000 <0,005. Dengan demikian, dapat disimpulkan bahwa musaqah berpengaruh terhadap tingkat kesejahteraan petani kelapa penggarap dan mempunyai pengaruh yang signifikan. Besarnya persentase pengaruh musaqah terhadap tingkat kesejahteraan petani kelapa sebesar $25,3 \%$, sedangkan sisanya sebesar 74,7\% dipengaruhi oleh variabel lain yang tidak termasuk dalam penelitian ini.

\section{PENDAHULUAN}

Salah satu bidang muamalah yang sangat penting bagi masyarakat adalah bidang pertanian. Karena dengan adanya lahan yang tersedia dapat membantu masyarakat dalam memenuhi kebutuhan hidupnya sehari-hari. Pengelolaan lahan dapat dikerjakan sendiri ataupun dengan cara diserahkan kepada orang lain untuk mengelolanya.

Dalam rangka mencapai kesejahteraan, manusia diperbolehkan bahkan dianjurkan untuk saling bekerjasama. Salah satu bentuk kerjasama yang dapat dilakukan adalah kerjasama dalam bidang pertanian yaitu kerjasama mengelola lahan pertanian antara pemilik lahan dengan petani penggarap.

Dimana nantinya hasil dari kerjasama tersebut dibagi sesuai dengan kesepakatan yang telah disepakati sebelumnya. Islam menaruh perhatian yang besar terhadap kegiatan pertanian dan cabangnya. Perhatian tersebut terlihat dari al-qur'an dan hadist 
Pengaruh Musaqah terhadap Tingkat Kesejahteraan Petani Kelapa

serta kehidupan Rasulullah saw dan para sahabatnya yang berkaitan dengan pertanian. Kerjasama pertanian dalam Islam ada tiga istilah, salah saatunya adalah musaqah. Musaqah adalah sebuah bentuk kerjasama antara pemilik kebun dan petani penggarap dengan tujuan agar kebun itu dipelihara, dan dirawat sehingga memberikan hasil yang maksimal, kemudian hasil tersebut sebagian menjadi bagian (upah) bagi penggarap yang mengurusnya sesuai dengan kesepatakan yang mereka buat.

Menurut istilah, al-musaqah didefinisikan oleh para ulama sebagaimana dikemukakan oleh Abdurrahman al-Jaziri, al-musaqah ialah akad untuk pemeliharaan pohon kurma, tanaman (pertanian) dan yang lainnya dengan syarat-syarat tertentu. (Suhendi, 2016)

Sebagaimana yang terdapat dalam hadist Ibnu umar berkata bahwa Rasulullah saw pernah memberikan tanah dan tanaman kurma di Khaibar kepada Yahudi Khaibar untuk dipelihara dengan mempergunakan peralatan dan dana mereka. Sebagai imbalan, mereka memperoleh persentase tertentu dari hasil panen. (Antonio, 2001).

Dengan demikian akad musaqah adalah sebuah bentuk kerjasama antara pemilik kebun dan petani penggarap dangan tujuan agar kebun itu dipelihara dan dirawat sehingga memberikan hasil yang maksimal. Kemudian, segala sesuatu yang dihasilkan pihak kedua berupa buah merupakan hak bersama antara pemilik dan penggarap sesuai dengan kesepakatan yang mereka buat. (Abdul Rahman Ghazaly , 2010)

Pensyariatan musaqah dalam islam adalah untuk menghilangkan kesulitan diantara sesama manusia. Orang yang mempunyai banyak lahan pertanian kadang mempunyai kesulitan untuk mengelola lahan pertaniannya, baik karena tidak mampu atau mungkin tidak punya waktu untuk mengelolanya. Di pihak lain ada orang yang tidak mempunyai lahan pertanian, tetapi mempunyai kemampuan untuk mengelola lahan. Maka dari itu, musaqah bertujuan untuk mewujudkan kerja sama saling menguntungkan diantara sesama manusia. (Rozalinda, 2016)

Pemilik lahan pertanian yang tidak mampu mengelola lahan pertaniannya terbantu oleh petani penggarap yang tidak mempunyai lahan pertanian. Lahan pertaniannya tetap produktif dan menghasilkan keuntungan. Petani penggarap mendapat kesempatan meningkatkan kesejahteraan ekonominya dari bagi hasil yang diperoleh dalam mengelola lahan pertanian tersebut. Dengan adanya kerjasama ini diharapkan kedua belah pihak sama-sama memperoleh keuntungan antara pemilik lahan dan petani penggarap sehingga dapat terbantu untuk memenuhi kebutuhan ekonominya.

Di desa Sungai Simbar Kecamatan Kateman pekerjaan masyarakatnya hampir $100 \%$ petani kelapa. Di antara banyaknya petani kelapa, ada yang memiliki kebun kelapa sendiri dan ada juga yang tidak memiliki kebun sendiri. Mereka yang memiliki kebun kelapa mengerjakan kebunnya sendiri dan ada juga yang memberikan kepada petani penggarap untuk mengelola dan merawat kebunnya. Berbeda dengan petani kelapa yang tidak memiliki kebun sendiri, mereka mengelola kebun milik orang lain sebagai mata pencaharian mereka untuk memenuhi kebutuhannya sehari-hari.

\section{Al-Muqayyad}

Vol 4 No 2 (2021) 
Mayoritas petani kelapa di Desa Sungai Simbar Kecamatan Kateman menggunakan kerjasama musaqah atau biasa lebih dikenal dengan bagi hasil. Bagi hasil dilakukan sesuai kesepakatan awal antara pemilik kebun dan petani penggarap, ada dua macam bentuk bagi hasil yang digunakan oleh para petani kelapa di Desa Sungai Simbar yaitu: bagi dua dan bagi lima. Namun yang paling sering disepakati yaitu bagi hasil dalam bentuk bagi dua, karena dengan bagi dua, penggarap merasa mendapatkan hasil sesuai dengan pekerjaan yang dikerjakannya. Kita ketahui bahwa pekerjaan petani kelapa ini adalah pekerjaan berat dan melalui beberapa tahap pengerjaan sebelum mendapatkan hasil, dan dalam satu tahap pengerjaan memerlukan beberapa hari untuk dapat menyelesaikannya.

Masyarakat Desa Sungai Simbar menggunakan kerjasama musaqah karena kebun yang digarap sudah memiliki pohon dan tugas penggarap hanya membersihkan kebun, merawat pohon dan memanen apabila sudah tiba masa panen. Sebagaimana menurut ulama syafi'iyah musaqah adalah mempekerjakan orang lain untuk menggarap kurma atau pohon anggur, dengan perjanjian penggarap akan menyiram dan mengurusnya, kemudian buahnya untuk mereka berdua dibagi sesuai kesepakatan di awal akad.

Musaqah adalah bentuk yang lebih sederhana dari muzara'ah, dimana muzara'ah adalah kerjasama pengelolaan lahan pertanian dimana lahan belum memiliki pohon dan benih diberikan dari pemilik lahan, kemudian penggarap mengelola lahan beserta benih yang telah diberikan, sedangkan musaqah penggarap hanya bertanggung jawab atas penyiraman dan pemeliharaan pohon serta memanen buah yang sudah siap panen, dimana lahan yang digarap sudah memiliki pohon.

Berdasarkan hasil wawancara awal dengan salah seorang penggarap masih ada sebagian penggarap melakukan hal-hal yang melenceng dari kesepakatan kerjasama dimana penggarap mengambil atau mengolah buah hasil panen tanpa sepengetahuan pemilik kebun, seperti mengolahnya menjadi minyak kelapa beberapa ratus buah dan tempurungnya dijadikan arang lalu hasil tersebut dijual dalam bentuk minyak dan arang tanpa sepengetahuan pemilik kebun., hal lain juga dipapar kan oleh salah seorang narasumber beliau menyatakan bahwa yang sering terjadi adalah pendesakan ke penggarap, awal kesepakatan kerjasama ada yang menentukan batas lama pengerjaan dan ada juga sebagian tidak ada menentukan batas waktu pengerjaannya, setelah kesepakatan berjalan beberapa minggu, tiba-tiba pemilik kebun mendesak penggarap untuk dapat menyelesaikan segera pengerjaannya dan memberikan tempo beberapa hari. Sehingga penggarap merasa terdesak dengan perintah dari pemilik kebun.

Dari pemaparan diatas, adapun tujuan dari pennelitian untuk mengetahui pengaruh musaqah terhadap tingkat kesejahteraan petani kelapa 
Pengaruh Musaqah terhadap Tingkat Kesejahteraan Petani Kelapa

\section{METODE}

Penelitian ini merupakan penelitian lapangan yang menggunakan pendekatan kuantitatif, yaitu menganalisis dalam bentuk data-data yang berupa angka. Data yang digunakan dalam penelitian ini yaitu data primer. Data primer merupakan data yang langsung diperoleh dari sumber data pertama di lokasi penelitian. Data diperoleh dari hasil kuesioner yang dibagikan kepada responden, yaitu petani kelapa Desa Sungai Simbar, Kecamatan Kateman, Kabupaten Indragiri Hilir.

Adapun metode penelitian ini adalah penelitian kuantitatif. Penelitian kuantitatif dapat diartikan sebagai metode penelitian yang berlandaskan pada filsafat positivisme, digunakan untuk meneliti pada populasi atau sampel tertentu pengumpulan data menggunakan instrumen penelitian, analisis data yang bersifat kuantitatif atau statistik dengan tujuan untuk menguji hipotesis yang telah diterapkan.

Tempat yang dijadikan penelitian adalah Desa Sungai Simbar, Kecamatan Kateman, Kabupaten Indragiri Hilir. Sedangkan waktu penelitian ini dilaksanakan kurang lebih selama 3 bulan. Terhitung dari tanggal 02 Juli 2020 sampai dengan 04 Oktober 2020.

Subjek dalam penelitian ini adalah Petani Kelapa di Desa Sungai Simbar Kecamatan Kateman Kabupaten Indrgiri Hilir. Objek penelitian ini adalah Pengaruh Musaqah Terhadap Tingkat Kesejahteraan Petani Kelapa di Desa Sungai Simbar Kecamatan Kateman Kabupaten Indragiri Hilir

Populasi adalah keseluruhan objek yang akan diteliti. (syahrudin, 2014) Adapun populasi dalam penelitian ini adalah Petani Kelapa Penggarap di Desa Sungai Simbar Kecamatan Kateman sebanyak 420 orang. Sampel adalah sebagian anggota populasi yang diambil dengan menggunakan teknik pengambilan sampling. (Hardani, 2014) Dalam penelitian ini teknik sampel yang digunakan adalah random sampling (pengambilan data secara acak). Dalam penarikan sampel secara random, setiap unsur dari keseluruhan populasi mempunyai kesempatan yang sama untuk dipilih.

Teknik pengumpulan data merupakan langkah yang paling strategis dalam penelitian, karena tujuan utama dari penelitian adalah mendapatkan data. Tanpa mengetahui teknik mengumpulan data, maka peneliti tidak akan mendapatkan data yang memenuhi standar data yang ditetapkan. Pengumpulan data merupakan langkah yang paling penting, karena data yang dikumpulkan akan digunakan untuk memecahkan masalah yang sedang diteliti atau untuk menguji hipotesis yang telah dirumuskan. Untuk mengumpulkan data dan informasi yang diperoleh dalam penelitian ini, penulis menggunakan teknik pengumpulan data.

Kuesioner adalah teknik pengumpulan data yang dilakukan dengan cara memberi seperangkat pertanyaan atau pernyataan tertulis kepada responden untuk dijawabnya. Dalam penelitian ini kuesioner (Angket) ditujukan kepada para Petani Kelapa Penggarap di Desa Sungai Simbar, Kecamatan Kateman Kabupaten Indragiri Hilir. Dokumentasi adalah rekaman peristiwa, berupa foto atau catatan lainnya yang

\section{Al-Muqayyad}

Vol 4 No 2 (2021) 
berhubungan dengan peristiwa. (Bungin, 2010)Dokumentasi dapat berupa rekaman atau dokumen tertulis, seperti arsip data base, surat-menyurat, rekaman gambar, dan bendabenda peninggalan yang berkaitan dengan suatu peristiwa. Dokumentasi dalam penelitian ini dilakukan untuk memperoleh data-data yang dibutuhkan serta foto-foto kegiatan.

Analisis data merupakan berkenaan perhitungan untuk menjawab rumusan masalah dan pengajuan hipotesis yang diajukan. Untuk menganalisis data dalam penelitian ini digunakan analisis regresi sederhana, untuk mengetahui pengaruh musaqah terhadap tingkat kasejahteraan petani kelapa di Desa Sungai Simbar Kecamatan Kateman Kabupaten Indragiri Hilir.

Analisis regresi dipergunakan untuk menelaah hubungan antara dua variabel atau lebih, terutama untuk menelusuri pola hubungan yang modelnya belum diketahui dengan sempurna, atau untuk mengetahui bagaimana variasi dari beberapa variabel independen mempengaruhi variabel dependen dalam suatu fenomena yang kompleks. (Sambas Ali Muhidin, 2007)

Regresi sederhana bertujuan untuk mempelajari hubungan antara dua variabel. Pengujiannya menggunakan alat bantu program SPSS versi 23 dan juga manual dengan rumus yang digunakan untuk menghitung persamaan garis regresi sederhana

\section{HASIL DAN PEMBAHASAN}

Uji validitas akan menguji masing-masing variabel yang digunakan dalam penelitian ini. Jumlah variabel independen yaitu musaqah (X) memuat 10 pernyataan dan variabel dependen yaitu tingkat kesejahteraan (Y) memuat 8 pernyataan. Sehingga keseluruhan variabel penelitian ini memuat 18 pernyataan yang harus dijawab oleh responden. Valid tidaknya pernyataan yang digunakan dalam penelitian ini yaitu dengan derajat kebebasan atau degree of freedom $(\mathrm{df})=\mathrm{n}-2$ dalam hal ini adalah jumlah sampel. Dalam penelitian ini besarnya df dapat dihitung 201-2 =199 dengan alpha 0,05 maka di dapat $r$ tabel sebesar 0,1384 .

Adapun hasil pengujian validitas dengan menggunakan alat bantu SPSS versi 23 agar lebih efisien. Maka diperoleh hasil validitas yang dapat dilihat pada tabel dibawah ini

Tabel 3.1

Hasil uji validitas variabel $\mathbf{x}$ (musaqah)

\begin{tabular}{ccccc}
\hline $\begin{array}{c}\text { Variabel } \\
\text { Penelitian }\end{array}$ & $\begin{array}{c}\text { Butir Item } \\
\text { Pernyataan }\end{array}$ & $\begin{array}{c}\text { Nilai } \\
r_{\text {hitung }}\end{array}$ & $\begin{array}{c}\text { Nilai } \\
r_{\text {tabel }}\end{array}$ & Ket. \\
\hline & 1 & 0,279 & 0,1384 & Valid \\
& 2 & 0,359 & 0,1384 & Valid \\
Musaqah & 3 & 0,438 & 0,1384 & Valid \\
& 4 & 0,376 & 0,1384 & Valid \\
& 5 & 0,429 & 0,1384 & Valid \\
& 7 & 0,345 & 0,1384 & Valid \\
& 7 & 0,301 & 0,1384 & Valid
\end{tabular}

Al-Muqayyad

Vol 4 No 2 (2021) 
Pengaruh Musaqah terhadap Tingkat Kesejahteraan Petani Kelapa

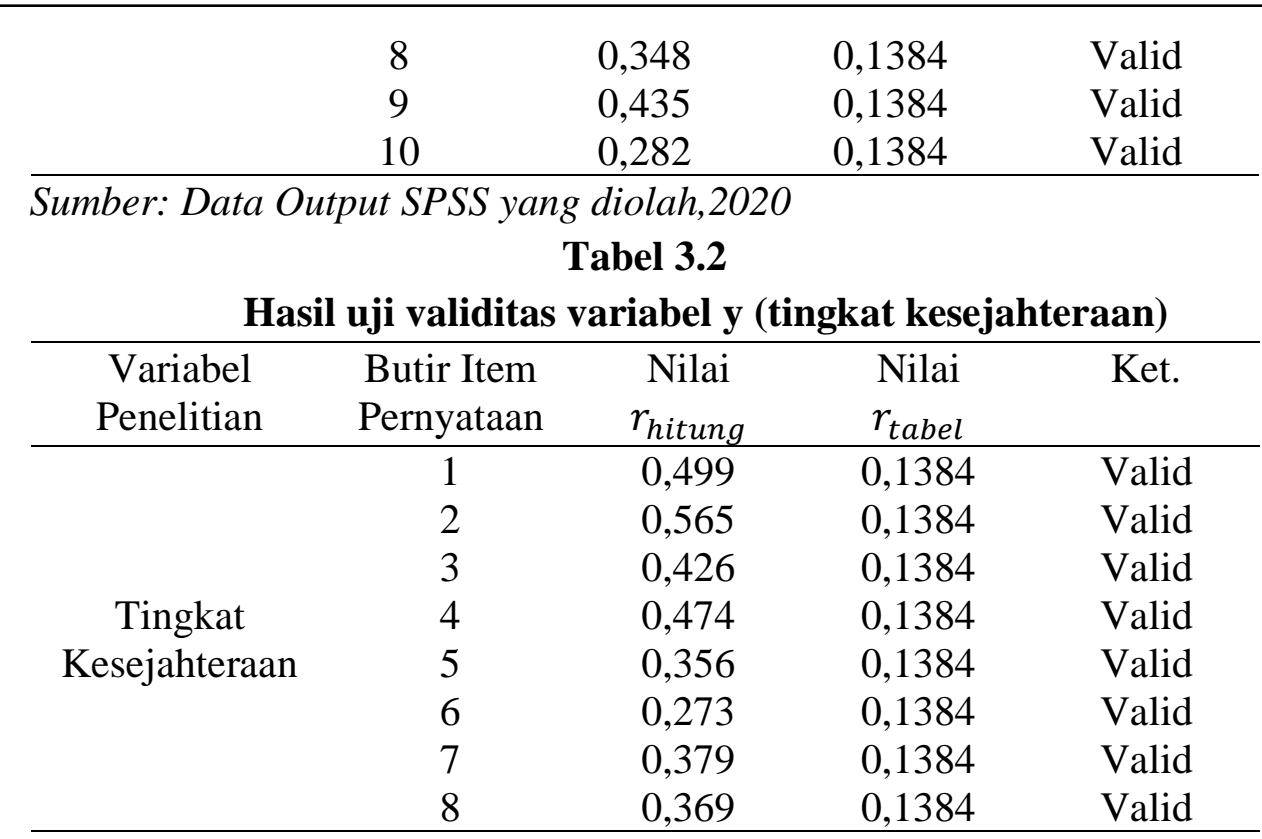

Sumber: Data Output SPSS yang diolah,2020

Berdasarkan tabel diatas, dapat diketahui bahwa nilai dari $r_{\text {hitung }}$ keseluruhan yang diuji bernilai positif dan lebih besar daripada $r_{\text {tabel }}$. Maka dapat diambil kesimpulan bahwa keseluruhan penyataan pada angket dinyatakan valid.

Uji realibilitas digunakan untuk mengukur variabel penelitian. Untuk mengukur uji realibilitas dengan menggunakan tehnik Cronbach Alpha. Suatu variabel penelitian dikatakan realibel jika memberikan nilai Cronbach Alpha lebih besar daripada nilai Alpha yaitu sebesar 0,60. Setelah dilakukan uji realibilitas dengan menggunakan program SPSS versi 23 , maka diperoleh hasil yang dapat dilhat pada tabel dibawah ini:

Tabel 3.3

Hasil uji realibilitas variabel $\mathrm{x}$ (musaqah) dan variabel y (tingkat kesejahteraan)

\begin{tabular}{lccc}
\hline \multicolumn{1}{c}{ Variabel Penelitian } & $\begin{array}{c}\text { Cronbach's } \\
\text { Alpha }\end{array}$ & Nilai $\alpha$ & Ket. \\
\hline Musaqah (X) & 0,614 & 0,60 & Realibel \\
Tingkat Kesejahteraan (Y) & 0,643 & 0,60 & Realibel \\
\hline
\end{tabular}

Sumber: Data Output SPSS yang diolah,2020

Berdasarkan tabel diatas dapat dilihat bahwa variabel penelitian musaqah dan tingkat kesejahteraan dinyatakan realibel, ini dapat dilihat dengan membandingkan nilai Cronbach Alpha > nilai $\alpha$ (alpha).

Analisis data merupakan berkenaan perhitungan untuk menjawab rumusan masalah dan pengajuan hipotesis yang diajukan. Untuk menganalisis data dalam penelitian ini digunakan analisis regresi sederhana secara manual dan dengan menggunakan bantuan dari program SPSS versi 23, untuk mengetahui pengaruh musaqah terhadap tingkat kesejahteraan petani kelapa di Desa Sungai Simbar Kecamatan Kateman Kabupaten Indragiri Hilir. 
Tabel 3.4

Analisis regresi sederhana

Coefficients

\begin{tabular}{ccccccc} 
No & $\begin{array}{c}\text { Nama } \\
\text { Variabel }\end{array}$ & \multicolumn{2}{c}{$\begin{array}{c}\text { Unstandardized } \\
\text { Coefficients }\end{array}$} & $\begin{array}{c}\text { Standardized } \\
\text { Coefficients }\end{array}$ & & \\
& & B & Std.Error & Beta & T & Sig. \\
\hline \multirow{2}{*}{1} & Konstanta & 24.377 & 2.599 & & 9.3 & .000 \\
& & & & & 80 & .00 \\
& Musaqah & .246 & .058 & .287 & 4.2 & .000 \\
\hline
\end{tabular}

Sumber: Data Output SPSS yang diolah,2020

Dari tabel di atas mengenai persamaan regresi, diketahui nilai konstanta $(\alpha)=$ 24,377 dan beta $(b)=0,246$. Dari tabel tersebut diperoleh persamaan perhitungannya adalah sebagai berikut:

$$
\begin{aligned}
& \hat{Y}=a+b X \\
& \hat{Y}=24,377+0,246 \mathrm{X}
\end{aligned}
$$

Dari persamaan tersebut dapat di ambil kesimpulan sebagai berikut:

1. Konstanta sebesar 24,377 mengandung arti bahwa nilai konsisten variabel Tingkat Kesejahteraan adalah sebesar 24,377.

2. Koefesien regresi sebesar 0,246 menyatakan bahwa setiap penambahan 1 satuan pada variabel X (Musaqah) akan meningkatkan variabel Y (Tingkat Kesejahteraan) sebesar 0,246. Sebaliknya, jika pengurangan 1 satuan pada variabel X (Musaqah) maka akan menurunkan variabel Y (Tingkat Kesejahteraan) sebesar 0,246.

Untuk menjawab hipotesis pertama dan kedua dalam penelitian ini maka digunakan uji statistik t. Uji statistik t digunakan untuk menjawab pertanyaan apakah variabel independan (musaqah) secara individual mempunyai pengaruh yang signifikan terhadap variabel dependen (tingkat kesejahteraan). Asumsinya adalah:

1. Jika probabilitas (signifikansi) lebih besar dari 0,05 $(\alpha)$, maka variabel independen secara individual tidak berpengaruh terhadap variabel dependen.

2. Jika probabilitas (signifikansi) lebih kecil dari $0,05(\alpha)$, maka variabel independen secara individual berpengaruh terhadap variabel dependen.

Hasil uji parsial (uji t) dengan menggunakan bantuan program SPSS versi 23, dapat di lihat di table dibawah ini: 
Pengaruh Musaqah terhadap Tingkat Kesejahteraan Petani Kelapa

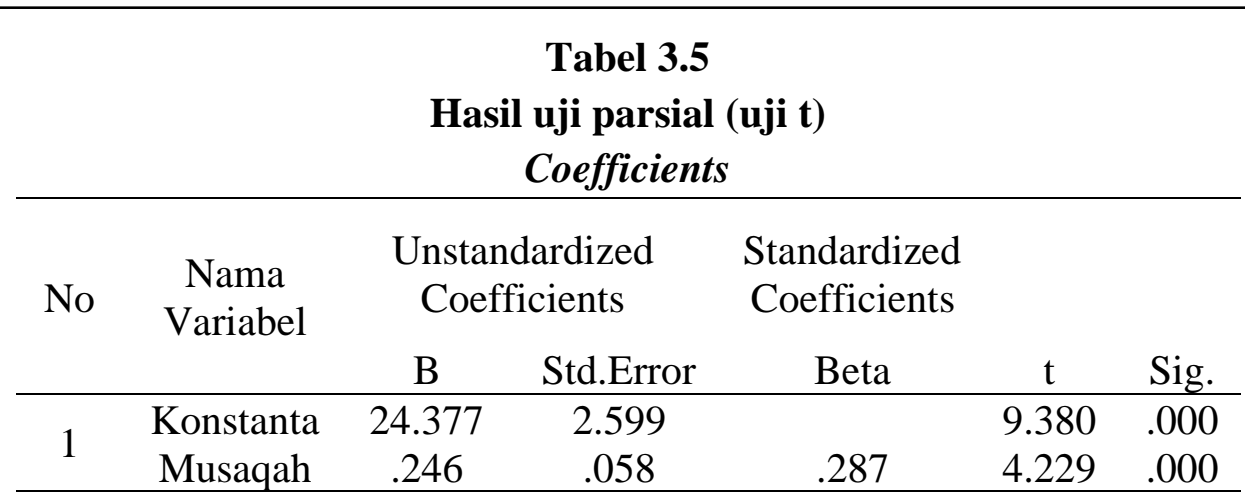

Sumber: Data Output SPSS yang diolah,2020

Pada tabel di atas, maka dapat ditarik kesimpulan berdasarkan nilai signifikansi: dari tabel Coefficients diperoleh nilai signifikansi sebesar $0,000<0,005$, sehingga dapat diartikan bahwa variabel Musaqah (X) berpengaruh terhadap variabel Tingkat Kesejahteraan (Y). Berdasarkan nilai t diketahui nilai t_hitung 4,229 > t_tabel 1,972 Untuk mencari hasil t_tabel dengan cara berikut:

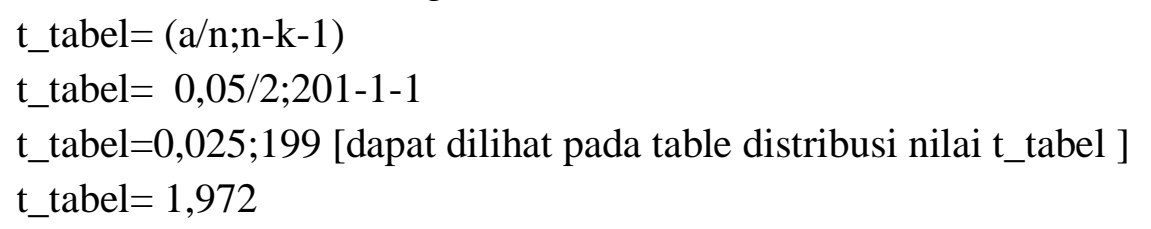

Sehingga dapat diartikan bahwa variabel Musaqah (X) berpengaruh terhadap variabel Tingkat Kesejahteraan (Y).

Dari hasil Uji t diatas diketahui bahwa variabel $\mathrm{X}$ (Musaqah) memiliki nilai signifikan sebesar 0,000 < 0,005 maka disimpulkan bahwa H0 ditolak dan Ha diterima, hal ini berarti terdapat pengaruh yang signifikan secara parsial antara variabel $\mathrm{X}$ (Musaqah) terhadap variabel Y (Tingkat Kesejahteraan). Selanjutnya jika dilihat dari nilai thitung sebesar 4,229 dan ttabel 1,972 hasil diperoleh thitung > ttabel. Sehing ga disimpulkan bahwa variabel $\mathrm{X}$ (Musaqah) secara parsial berpengaruh signifikan terhadap variabel Y (Tingkat Kesejahteraan).

Koefisien determinasi memiliki fungsi untuk menjelaskan sejauh mana pengaruh variabel independen (Musaqah) dalam menerangkan variabel dependen (tingkat kesejahteraan) dengan melihat R Square. Uji R Square (R2) dilakukan dengan bantuan program SPSS versi 23. Berikut ini merupakan table hasil uji R Square (R2).

Tabel 3.6

Hasil uji koefisien determinasi

Model summary

\begin{tabular}{ccccc}
\hline No & $\mathrm{R}$ & R Square & $\begin{array}{c}\text { Adjusted R } \\
\text { Square }\end{array}$ & $\begin{array}{c}\text { Std.Error of } \\
\text { the Estimate }\end{array}$ \\
\hline 1 & .287 & .253 & .378 & 1.50646 \\
\hline
\end{tabular}

Sumber: Data Output SPSS yang diolah,2020

Al-Muqayyad

Vol 4 No 2 (2021) 
Diketahui bahwa koefisien determinasi (R2) adalah sebesar 0,253 artinya kombinasi variabel independen $(\mathrm{X})$ yaitu musaqah terhadap variabel dependen $(\mathrm{Y})$ tingkat kesejahteraan sebesar 25,3\%. Hal ini menunjukkan bahwa dengan menggunakan model regresi yang didapatkan pada tabel diatas variabel independen tersebut terpengaruh terhadap variabel dependennya yaitu tingkat kesejahteraan, dan sisanya sebesar $74,7 \%$ dipengaruhi oleh variabel lain yang tidak termasuk dalam analisa atau penelitian regresi ini.

\section{SIMPULAN}

Berdasarkan hasil penelitian yang telah peneliti paparkan di atas, maka dapat ditarik kesimpulan. Hasil pengujian dan perhitungan regresi linear sederhana yang telah dilakukan, menunjukkan $\hat{Y}=24,377+0,246 X$. Koefesien regresi sebesar 0,246 menyatakan bahwa setiap penambahan 1 satuan pada variabel X (Musaqah) akan meningkatkan variabel Y (Tingkat Kesejahteraan) sebesar 0,246. Sebaliknya, jika pengurangan 1 satuan pada variabel X (Musaqah) maka akan menurunkan variabel Y (Tingkat Kesejahteraan) sebesar 0,246. Dengan demikian semakin baik musaqah maka akan semakin tinggi pula tingkat kesejahteraan petani kelapa di Desa Sungai Simbar Kecamatan Kateman. Hasil uji $\mathrm{T}$ pada tabel coefficients diperoleh nilai signifikansi sebesar $0,000<0,005$ dan diketahui nilai t_hitung 4,229>t_tabel 1,972 maka disimpulkan bahwa H0 ditolak dan Ha diterima, hal ini berarti terdapat pengaruh yang signifikan secara parsial antara variabel X (Musaqah) terhadap variabel Y (Tingkat Kesejahteraan). Hasil uji koefisien determinasi (R2) mendapatkan hasil R Square sebesar 0,253 atau 25,3\% artinya kombinasi variabel independen (X) yaitu musaqah terhadap variabel dependen (Y) tingkat kesejahteraan sebesar 25,3\%. Hal ini menunjukkan bahwa persentase pengaruh musaqah (X) terhadap tingkat kesejahteraan petani kelapa (Y) adalah sebesar 25,3\% dan sisanya sebesar 74,7\% dipengaruhi oleh variabel lain yang tidak termasuk dalam penelitian ini.

\section{REFERENSI}

Abdul Rahman Ghazaly, d. (2010). Fiqih Muamalat. Jakarta: Kencana Prenada Group.

Antonio, M. S. (2001). Bank Syariah dari Teori ke Praktek. Jakarta: Gema Insani.

Bungin, B. (2010). Metodologi Penelitian Kuantitatif. Jakarta: Prenada Media Group.

Hardani, d. (2014). Metode Penelitian Kuantitatif. Bandung: Citapustaka media.

Rozalinda. (2016). Fikih Ekonomi Syariah dan Implementasinya pada Sektor Keuangan Syariah . Jakarta: PT. Raja Grafindo Persada.

Sambas Ali Muhidin, M. (2007). Analisis Korelasi, Regresi, dan Jalur Dalam Penelitian. Bandung: Pustaka Setia.

Sanusi, A. (2017). Metodologi Penelitian Bisnis. Jakarta: Salemba Empat.

Suhendi, H. (2016). Fiqih Muamalah. Jakarta: Gema Insani.

Syahrudin, S. (2014). Metodologi Penelitian Kuantitatif. Bandung: Citapustaka Media. 